postexposure skin-test conversion rates at the hospital have been less than $1 \%$.

\section{REFERENCES}

1. Dooley SW, Villarino ME, Lawrence M, et al. Nosocomial transmission of tuberculosis in a hospital unit for HIV-infected patients. JAMA 1992;267:2632-2634.

2. DiPerri G, Cruciani M, Danzi MC, et al. Nosocomial epidemic of active tuberculosis among HIV-infected patients. Lancet 1989;2:1502-1504.

3. Daley CL, Small PM, Schecter GF et al. An outbreak of tuberculosis with accelerated progression among persons infected with the human immunodefiency virus: an analysis using restriction-fragment-length polymorphisms. N Engl J M ed 1992;326:231-235.

4. Centers for Disease Control. Transmission of multi-drug resistant tuberculosis from an HIV-positive client in a residential substance-abuse treatment facilitv-Michigan. MMWR 1991:40:129-131.

5. Nolan CM. Elarth AM. Barr H. Saeed AM. Risser DR. An outbreak of tuberculosis in a shelter for homeless men: a description of its evolution and control. Am Rev Respir Dis 1991;143:257-261.

6. Centers for Disease Control. Drug-resistant tuberculosis among the homeless-Boston. M M W R 1985;34:429-431.

7. Braun MM, Truman BI, Maguire B, et al. Increasing incidence of tuberculosis in a prison inmate population. JAMA1989;261:393397.

8. Centers for Disease Control. Prevention and control of tuberculosis in correctional institutions: recommendations of the Advisory Committee for the Elimination of Tuberculosis. M M WR 1989;38:313-320, 325 .

9. Edlin BR. Tokars JI. Grieco MH. et al. An outbreak of multidrugresistant tuberculosis among 'hospitalized patients with the acquired immunodeficiency syndrome. N Engl J Med 1992:326:1514-1521.

10. Pearson ML, Jereb JA, Frieden TR, et al. Nosocomial transmission of multidrug-resistant $M$ ycobacterium tuberculosis: a risk to patients and health care workers. Ann Intern M ed 1992:117:191-196.

11. Fischl MA, Uttamchandani RB, Daikos GL, et al. An outbreak of tuberculosis caused by multiple-drug-resistant tubercle bacilli among patients with HIV infection. Ann Intern M ed 1992;117:177183.

12. Beck-Sague C, Dooley SW, Hutton MD, et al. Hospital outbreak of multidrug-resistant $M$ ycobacterium tuberculosis infections: factors in transmission to staff and HIV-infected patients. JAMA 1992;268:1280-1286.

13. Centers for Disease Control. Nosocomial transmission of multidrug-resistant tuberculosis among HIV-infected personsFlorida and New York, 1988-1991. M M WR 1991;40:585-591.

14. Centers for Disease Control. Guidelines for preventing transmission of tuberculosis in health-care settings, with special focus on HI\&elated issues. M M WR 1990;39(RR-17):1-29.

15. Fraser VJ, Johnson K, Primack J, Jones M, Medoff G, Dunagan WC. Evaluation of rooms with negative pressure ventilation used for respiratory isolation in seven midwestern hospitals. Infect Control Hosp Ehdemiol 1993:14:623-628.

16. Riley RL, Nardell EA. Clearing the air. The theory and application of ultraviolet air disinfection. Am Rev Respir Dis 1989;139:12861294.

17. Valway SE, Richards SB, Kovacovich J, Greitinger RB, Crawford JT, Dooley SW. Outbreak of multi-drug-resistant tuberculosis in a New York State prison. Am J Epidemiol 1994;140:113-122.

18. Valway SE, Greifinger RB, Papania M, et al. Multidrug-resistant tuberculosis in the New York State prison system 1996-1991. J Infect D is 1994:170:151-156.

19. Centers for Disease Control. The use of preventive therapy for tuberculous infection in the United States: recommendations of the Advisory Committee for Elimination of Tuberculosis. M M WR 1990;39(RR-8):9-12.

20. Villarino ME, Dooley SW, Geiter LJ, Castro KG, Snider DE Jr. Management of persons exposed to multidrug-resistant tuberculosis. M M WR 1992;41(RR-11):59-71.

\title{
OSHA Expands Focused Inspections in Face of Limited Resources
}

\section{by Gina Pugliese, R N, M S $M$ edical $\mathrm{N}$ ews $\mathrm{E}$ ditor}

As part of the effort to operate under conditions of chronically limited enforcement resources, OSHA plans to expand focused inspections to general industry. This initiative is one of the agency's key objectives for fiscal year 1995. It is planned as part of an agency-wide move toward a more results-oriented enforcement approach, indicated OSHA administrator John Dear.

To date, OSHA's only experience with focused inspections has been in the construction industry, with inspections focusing on the four hazards that cause $90 \%$ of deaths and injuries. Only when one employer does not have an effective safety program in place is a complete wall-to-wall inspection done. These focused inspections in the construction industry began in October 1994 but have gotten off to a slow start. Complaints have arisen concerning lack of guidance for compliance officers conducting inspections and uncertainty of contractors in how to establish an effective safety program. OSHA anticipates targeting industries that have high injury and illness rates, and has indicated that it may look to labor and management groups to help develop these new approaches.

Experts predict that OSHA most likely will proceed cautiously in 1995 under the new Republican Congress and will focus on using existing authority rather than developing new regulations. An example of existing authority is the general duty clause of the Occupational Safety and Health Act, which OSHA is using in the absence of a specific TB standard to cite healthcare facilities for lack of TB control measures.

FROM: BNA Special Report: OSHA in 1995. BNA O ccupational Safety and $\mathrm{H}$ ealth Reporter January 11, 1995; 24(32): 1656-1659. 